student, in working upon his dissertation for a doctor's degree, comes across a few items which he must have, ... or go elsewhere to continue his work. Here are two situations constantly occurring in which the contributions of the Friends of the Library will be doubly or even trebly blessed.

"The association is not greatly interested in the size of a gift. What it particularly wants is a membership composed of sincerely interested persons who are watching and following the Library, and who will preach its mission among their friends.

"The library wants nearly everything that is printed, ... because the experience of three hundred years has shown that nobody can guess what is going to seem important next year or next century.

The last injunction to the Friends especially should be borne in mind:

"As the Librarians themselves have said: 'Don't throw any book or pamphlet away. Send everything to us and let us throw it away.' The Librarians would gladly hire one person who did nothing but throw away or dispose of material which was dumped in the basement, for he would earn his salary many times over by what he salvaged from a despised heap of outcast books."

\title{
$\mathfrak{I n}$ Attemoriam
}

ONCE more the Society has had the misfortune to lose a most valued member in Mr. Edward J. Pearson, who recently resigned as president of the New York, New Haven and Hartford Railroad. His career in railroad work bears a striking similarity to that of another former president of the same road, Mr. Howard Elliott, whose death we regretfully announced several months ago. Both men began their life work early, each in the position of rodman on one of the great western railroads, while still at college, Mr. Pearson being a graduate of Cornell. Like Mr. Elliott, he held positions of responsibility with more than one western system, and although a westerner by birth, he also came of New England ancestry.

In 1916, President Elliott made him supervisor of engineering and operation on the New York, New Haven and Hartford, and a year later, he succeeded Mr. Elliott as president. As his predecessor had once before rehabilitated the road when it was in a critical condition, so, as federal manager of the New Haven during 
the war, and as president again in the years following, Mr. Pearson also brought it through a trying period with great success. When he took over the road, it was faced with the possibility of receivership.

"It was a dramatic but fitting memorial to the success of his work," says the Boston Transcript, "that almost on the day of the announcement of his resignation last month, the directors voted a resumption of the annual dividends on the preferred and common stocks of the road, an action which had been presaged by the declaration of two special dollar dividends within the year."

The Transcript goes on with an account of the overwhelming difficulties which fell to Mr. Pearson's lot in his work with the New Haven and of his ability and firmness in meeting them.

"On the one hand, he had to produce satisfactory transportation and on the other to reduce the cost of that transportation so that the stockholders might receive some return. During the non-dividend paying period more than $\$ 92,000$,000 was invested in additions and betterments, which included the Cedar Hill 'hump,' the classification yard at Providence, the lengthening of tracks, the straightening of curves, and the purchase of new equipment. Mr. Pearson's method was to spend money to save money, and to introduce no economies that would impair efficiency. Legitimate economies were his goal, and at the very outset of his connection with the New Haven he devised a means of saving the road nearly $\$ 250,000$ annually on its scrap."

Among other monuments to his engineering skill are the first "hump" freight yards on the Pacific Coast. The thoroughness and devotion with which he threw himself into his work are exemplified by the occasion, before his connection with the New Haven, on which he walked its roadbed from New York to Springfield, rod and transit in hand, personally to examine the wharves, switching and terminal facilities, with the idea of applying their principles to like problems on the West Coast.

Mr. Pearson's death is a great loss to the business world, and no less to every circle with which he was connected, and among the number The Business Historical Society mourns the loss of his name from its rolls. 